\title{
THE PLIOCENE ENVIRONMENT OF ANTARCTICA
}

\author{
by Patrick G. Quilty \\ (with three text-figures)
}

QUiLTY, P.G., 1996 (xi): The Pliocene environment of Ant arctica. In Banks, M.R. \& Brown, M.J. (Eds): CLIMATICSUCCESSIONAND GLACIAL HISTORY OF THE SOUTHERN HEMISP HERE OVER THE LAST FIVE MILLION YEARS. Pap. Proc. R. Soc. Tasm. 130(2): 1-8. https://doi.org/10.26749/rstpp.130.2.1 ISSN 0080-4703. Australian Antarctic Division, Channel Highway, Kingston, Tasmania, Australia 7050, and Antarctic Cooperative Research Centre, University ofTasmania, GPO Box 252-80, Hobart, Tasmania, Australia 7001.

Debate continues about the environment of Antarctica during intervals in the Pliocene (5.2-1.8 Ma), particularly during the Late Pliocene (3.5-1.8 Ma). Two schools of thought - dynamic versus stable ice sheet - have developed. One hypothesis calls for the Antarctic ice sheet to vary dramatically, for Antarctica at times to be vegetated and for circum-antarcticwaters to be significantly warmer than at present. The other calls for a stable ice sheet, no vegetation and water temperatures much less varied. During 1995, the two sides converged by recognising that the change to conditions suitable for vegetation may not have been as marked as originally thought, and that oxygen isotope data may contain scope for more flexibility in interpretation than the stabilist view has supported. New data and new participants have emerged, but there is a long way to go in resolving the issue.

The key issue remains the age of the Sirius Group in the Transantarctic Mountains and the source of its contained diatoms. Diatoms of Pliocene age have been recovered from the Sirius Group bur also from modern ice, and this raises the question of whether the Sirius Group diatoms are actually in situ.

New data and re-evaluation of existing data are necessary. Ocean Drilling Program activity, particularly in the Prydz Bay region, and analysis of samples from the Prince Charles Mountains can be expected to contribute significantly to a solution, by providing more information on past temperatures and evidence of possible terrestrial vegetation.

Key Words: Antarctica, Pliocene, palaeoenvironment.

\section{INTRODUCTION}

Antarctica has loomed large in the question of global change for several reasons, including

(1) the potential impact of global change on the Antarctic (reduction in ice volume, changed sea-ice regime, vegetation invasion),

(2) the impact of changes in the Antarctic on other parts of the world (changed Southern Hemisphereweather patterns, sea-level rise, human migration), and

(3) the role of Antarctica as a source of records on past global change (global ice volume, past atmosphere composition) and for monitoring future change.

The Pliocene has become a global issue in itself, because there is a school of thought that suggests that the environment during parts of the Pliocene may be the environment into which the world will evolve under some scenarios of human-induced global change (referred to in Houghton et al. 1990). It is, thus, important to reconstruct the global Pliocene palaeoenvironment, to examine how different it was at key times, and to ascertain whether humanity would be content to live in such a world.

One issue that has led to a very contentious debate has been the matter of the Pliocene environment of the Antarctic continent. It is the purpose of this paper to review that debate briefly. For this paper, the Pliocene is taken as that part of geological time between 5.2 and $1.8 \mathrm{Ma}$ (Truswell et al. 1991) and is divided into the Early Pliocene, or Zanclean, and the Late Pliocene, or Piacenzian, with the Zanclean/Piacenzian boundary placed at about $3.5 \mathrm{Ma}$. Localities mentioned in the text are shown on figures 1 and 2 .

An evolving issue, not addressed here, concerns the role of variations in Northern Hemisphere ice volume (and, hence, sea level) during the Pliocene and perhaps earlier. Until recently, it was believed that Northern Hemisphere ice-sheet glaciation began at 2.6 Ma. Recent Ocean Drilling Program activity is providing evidence that this belief needs to be re-evaluated.

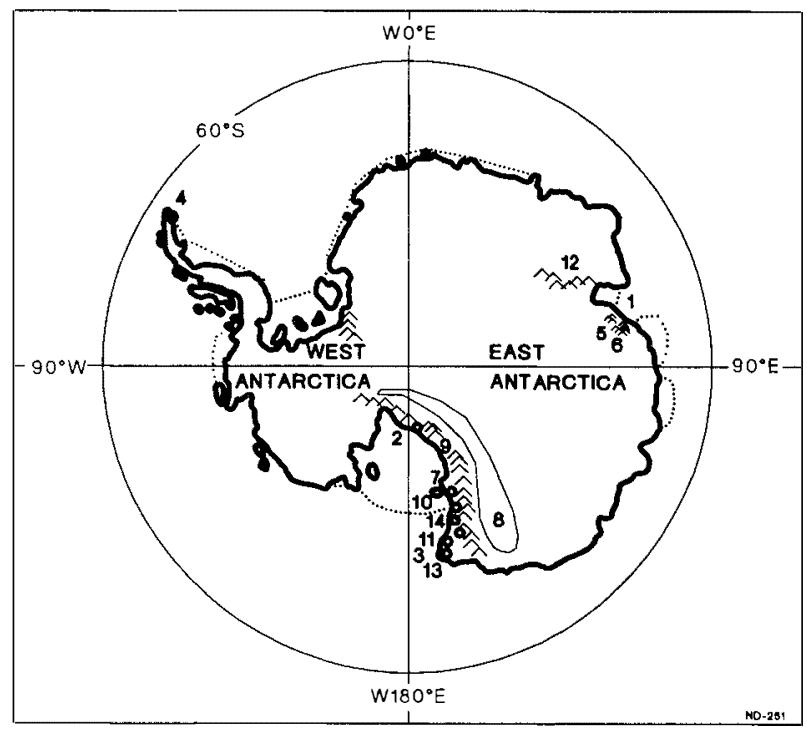

FIG. 1 -Antarctica showing localities mentioned in the text. 1-Prydz Bay; 2-Beardmore Glacier; 3-Prospect Mesa; 4Cockburn Island; 5-Marine Plain; 6-Vestfold Hills; 7-Dry Valleys Block; 8-Wilkes/Pensacola Basin; 9-Transantarctic Mountains; 10-Taylor Valley; 11-Wright Valley; 12-Prince Charles Mountains; 13-Admiralty Block; 14-Victoria Land Basin. 


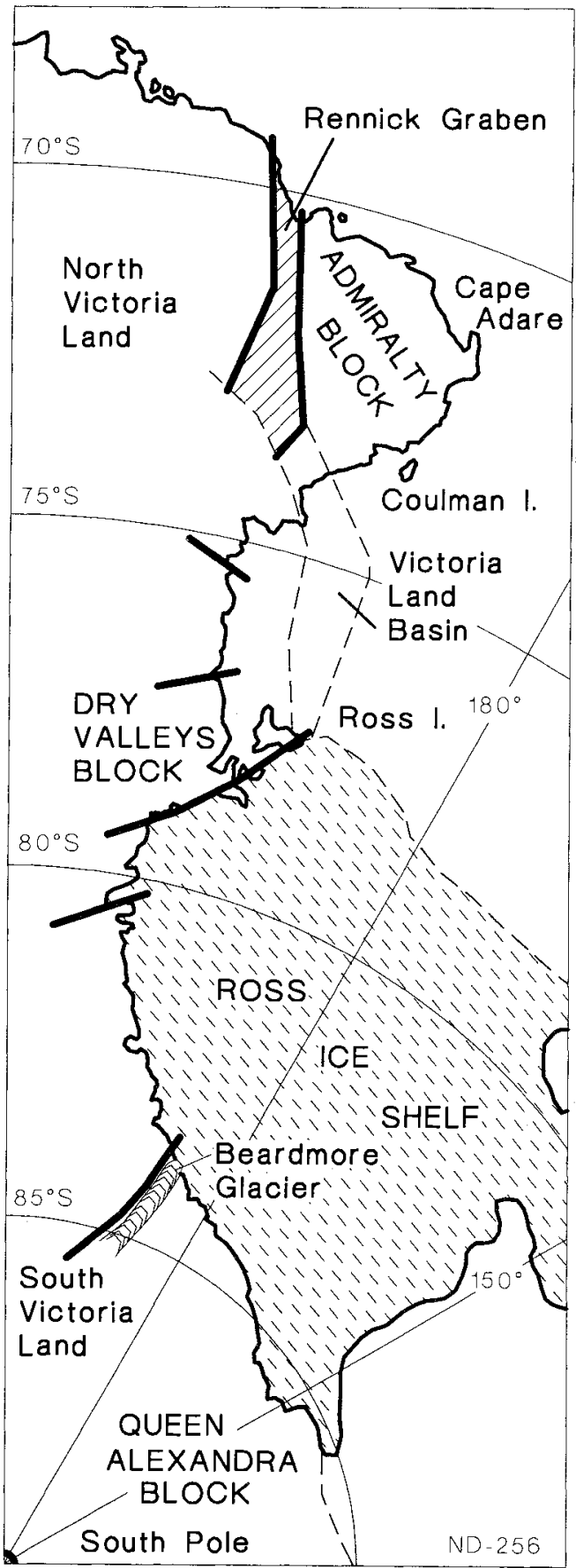

FIG. 2 - Details of localities in the Transantarctic Mountains-Victoria Land region.

\section{THE GLOBAL CONTEXT}

It is clear from many indicators that the global environment during the Pliocene (particularly prior to approximately 2.6 Ma) was different from that at present, and this often is raken to mean warmer prior to $2.6 \mathrm{Ma}$

Many marine oxygen isotope records (e.g. fig. 3 from Tiedemann et al. 1994) from the last 5 million years show that the modern global glacial regime began between 3.1 and $2.5 \mathrm{Ma}$ (Late Pliocene). Since then, the waxing and waning of Northern Hemisphere ice sheets, and the resultant sea-level changes, have generated an ocean system in which

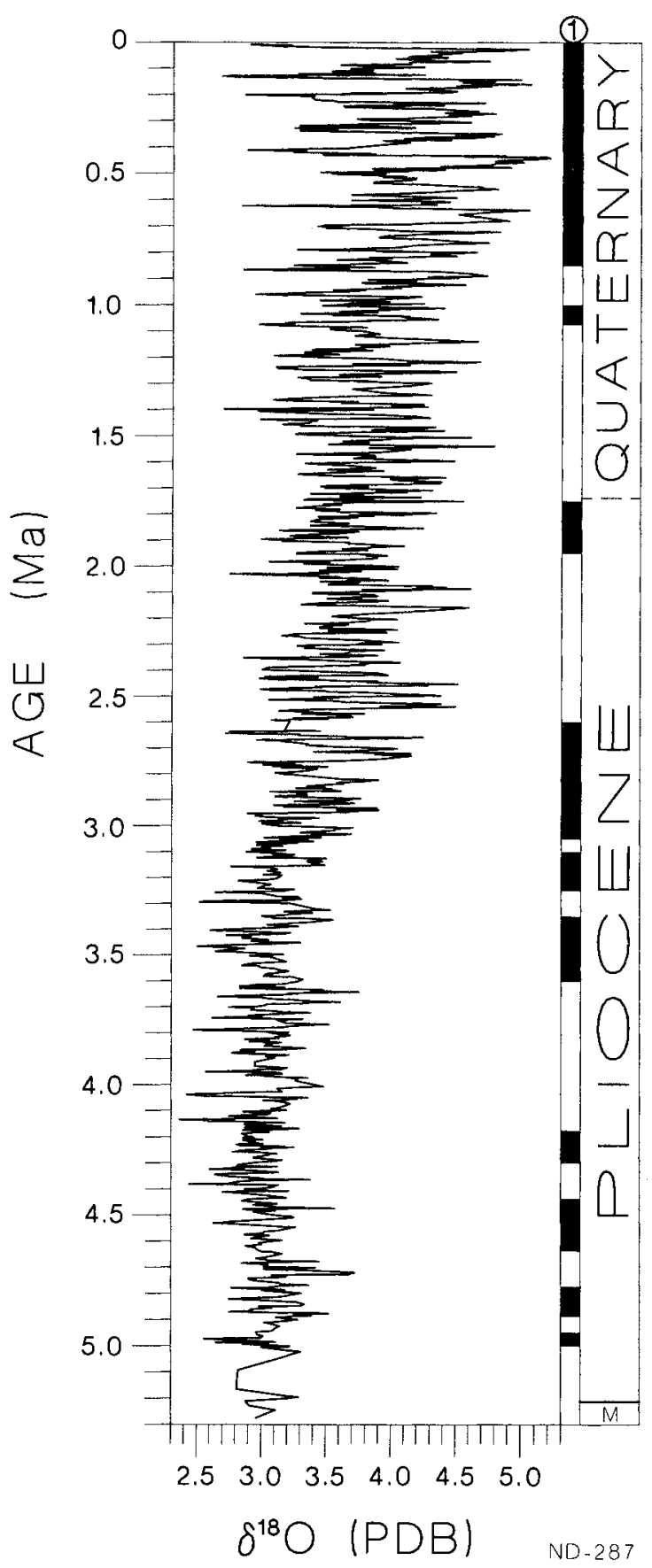

$F I G .3-$ Curve of oxygen isotope anomaly $\left(\delta^{18} O\right)$ for the last 5 Ma from Ocean Drilling Program Site 659, central Atlantic Ocean. Data obtained from the benthic foraminiferid Cibicidoides wuellerstorfi. Reproduced from data supplied by $R$. Tiedemann, from Tiedemann et al. (1994). I = magnetic polarity reversal pattern; black is normal and white reversed.

the long-term average $\delta^{18} \mathrm{O}$ has drifted over the last million years from $3 \%$ to the modern $4.0 \%$ (PDB), varying within the limits of +3 and $+5 \%$. The amplitude increases with time (e.g. Tiedemann et al. 1994, based on benthic foraminiferids) and the signal is dominated by the 100000 year cycle of the orbital forcing paramerers (Berger et al. 1982), especially over the last 0.6 million years. Prior to $2.6 \mathrm{Ma}$, there was a different regime, during which $\delta^{18} \mathrm{O}$ 
was centred on $3 \%$, varying between the limits of +2.5 and +3.4 with constant amplitude, and variation dominated by the 41000 -year cycle. The change from $41 \mathrm{ka}$ to $100 \mathrm{ka}$ dominated system occurred progressively between 3.15 and $2.5 \mathrm{Ma}$ (Tiedemann et al. 1994) as the Northern Hemisphere ice sheets became emplaced.

The change in $\delta^{18} \mathrm{O}$ baseline from 3 to $4 \%$ is due to global ice volume being smaller on average prior to $3 \mathrm{Ma}$, consistent with a generally higher sea level, perhaps enhanced by generally warmer and, thus, thermally expanded ocean waters. The higher sea level is also consistent with the view of Haq et al. (1987), based on analysis of global offshore seismic data, although there is debate on the calibration of the Haq et al. sea-level curve (see below).

Truswell (1990) referred to the "warm wet phase" in the Pliocene of the Lake George region, and Martin (1991) reviewed evidence for the existence, during a short interval, of rainforest vegetation (the Nothofagus phase) in the Early Pliocene of southeastern Australia, indicating that evidence of global warmth also comes from the terrestrial record. Martin's work suggests the presence of an interval of high, non-seasonal precipitation.

For Africa, DeMenocal (1995) has outlined the evolution of climate during the Plio-Pleistocene and reinforces the argument made by Tiedemann et al. (1994). DeMenocal's reference to a change in the mid-Pliocene, from closed canopy to open savannah with reduced rainfall and increased seasonality, indicates that similar changes occurred in Australia and Africa, but the evidence is not yet strong enough to show that the changes occurred simultaneously. $\mathrm{He}$ refers to considerably warmer and more humid subtropical West and East Africa during the Late Miocene to mid-Pliocene $(8-3 \mathrm{Ma})$. Some of the implications for the evolution of the human species are obvious.

\section{THE ANTARCTIC PLIOCENE DEBATE}

How did Antarctica fare in the context of a globally warmer Pliocene? Did the ice sheet on Antarctica remain the same size during a warmer Early Pliocene, or were there massive reducrions and expansions of ice-sheet volume?

The models (also used to label the antagonists) oversimplify the real situation. The debate, under either of the opposing hypotheses, has been about conditions during the Pliocene. Under the stabilist hypothesis, conditions throughout this entire interval are thought to have been uniform. This is an unrealistic approach, because we know how great global change can occur over much shorter intervals, for example, the last 18000 years since the Last Glacial Maximum (LGM), and as suggested for the Pliocene by the oxygen/carbon isotope record, now so well known (e.g. Tiedemann et al. 1994, Shackleton and co-workers). The Pliocene was about 3.4 million years long and the Early Pliocene (Haq et al. 1987) some 1.7 million years.

The issue of warmth and possible reduced ice volume arises at two different intervals in the Pliocene, one in the Early Pliocene and the other later in the Pliocene, the latter being the bigger problem.

The dynamicist argument is that the Antarctic ice sheet has undergone dramatic changes in volume over the last 5 million years.

The Early Pliocene warm interval (or short intervals) may have been parc of the global warmth at the time, and the changes called for in the size of the Antarctic ice sheet are relatively modest, compared with the $60-65 \%$ reduction postulated by the dynamicists for other intervals during the Pliocene. Early Pliocene warmth can be related to peaks in the $\delta^{18} \mathrm{O}$ baseline curve, and conditions may have been similar to or warmer (Tiedemann et al. 1994) than those today.

The Late Pliocene problem arises because of the occurrence of fossil roots, wood, leaves and pollen of Nothofagus and other vegetation in Sirius Group sediments adjacent to the Beardmore Glacier at $86^{\circ} \mathrm{S}$, in lake sediments contained within glacial sediments which are claimed, on the basis of fossil diatoms, to be younger than 2.6-3.0 million years, the age of the diatoms. The model proposed to explain the occurrence calls for a series of Late Pliocene (or even earliest Pleistocene) variations in ice-sheet volume, to transport and deposit the glacial sediments with their contained diatoms (probably from a marine source under the east Antarctic ice sheet in the Wilkes/Pensacola Basins), followed by climatic amelioration, to allow the development of lakes and vegetation. This model for the Antarctic seems to have developed independently of the model of a warmer earth during the Early Pliocene.

If there was a Late Pliocene dramatic expansion and reduction in Antarctic ice volume, there seems little evidence beyond the Antarctic.

\section{THE EVIDENCE FOR THE STABLE MODEL}

Shackleton \& Kennetr (1975) developed oxygen isotope curves from benthic and planktonic foraminiferids recovered from Deep Sea Drilling Project sites 277, 279 and 281 south of Tasmania and New Zealand. These curves were used to derive the evolution of Southern Hemisphere sea-water temperature and the history of Antarcric glaciation, but the level of discrimination in the Late Miocene and younger was rather poor. The history derived from these curves has been summarised again by Wilson (1995). It has become the generally accepted hypothesis. A key feature is a marked increase in marine $\delta^{18} \mathrm{O}$ in the Middle Miocene ( $14 \mathrm{Ma}$ ), which is taken to reflect the development of the East Antarctic ice sheet. The stable model suggests that this has been stable since then. The concept of a "warm", vegetated Pliocene Antarctica (in its entirety or during particular intervals) appears to be in conflict with this established hypothesis.

The stable hypothesis does not demand that there has been no deglaciation or rise in sea-water temperature; it simply places limits on what is seen as consistent with the data available.

Evidence for a stable Antarctic ice sheet comes from a variety of sources, including geomorphology, oxygen isotope records, the absence of palynological evidence of much vegetation, and possible preservation of ancient ice.

The supporters of the stable ice-sheet model held a symposium (the Vega Symposium) in 1993 and published the results (Sugden et al. 1993) to support their case.

Denton and a variety of co-auchors, in several detailed papers in Sugden et al. (1993), discussed the evolution of the landscape in the Dry Valleys region (for localities mentioned, see fig.1) of the Transantarctic Mountains. They ascribed the valleys and the general landscape to an origin in the Middle Miocene or earlier, arguing for very little evolution since that time, certainly nothing consistent with the history the dynamicist hypothesis would suggest. They 
compared the origin with that of several similar appearing arid zone landscapes elsewhere in the world and brought a grear deal of radiometric and other data together in support of their case. They believe that an expansion of the ice sheet late in the Pliocene, called for in the dynamicist hypothesis, would obliterate much of what is preserved in the Dry Valleys region and leave its own mark. They argued that the evidence is for an older and essentially unmodified landscape.

The marine oxygen isotope record has been used as definitive evidence against a dynamic ice sheet, especially by Kennett and co-workers (e.g. Kennert \& Hodell 1993 , 1995, Prentice \& Matthews 1991). Their argument is that the evidence opposes the concept of any significant decrease (in the extreme model of Kennett and Hodell, the limit is equivalent to a sea-level rise of $35 \mathrm{~m}$ but with very little increase in seawater temperature) in global ice volume, or of any significant increase in global seawater temperature (Kennett and Hodell allow a maximum temperature rise of $2.5^{\circ} \mathrm{C}$ but with little sea-level change). More recent, very detailed curves for the last few million years (such as those in Tiedemann et al. 1994) are used in support.

Burckle \& Pokras (1991) noted that palynology has not yielded evidence of vegetation other than from the plantbearing beds of the Sirius Formation. Despite the recognition of an Early Miocene flora (Jiang \& Harwood, in Kurtz 1955), the earlier statement is still generally true.

Sugden et al. (1995) reported the discovery, in the Dry Valleys region, of ice which they argued to be 8 million years old (Late Miocene) and, thus, deduced that there can have been no significant Pliocene warming of the Antarctic. Van der Wateren \& Hindmarsh (1995) registered some concerns about acceprance of the age of the ice. This occurrence needs to be studied further.

\section{THE EVIDENCE FOR THE DYNAMIC ICE-SHEET MODEL}

Webb \& Harwood (1991) have reviewed the debate and Harwood (1994) and Wilson (1995) have responded to criticisms of the hypothesis, including reference to many papers not cired here. Webb and Harwood are leaders in the reduced ice sheet/vegetated side of the debate. The intervals during which warm conditions are alleged to have occurred are in the Early Pliocene (about 4-3.5 Ma, consistent with the proposals of Ciesielski \& Weaver 1974, Keany 1978, Brady 1982, Quilty 1991) and Late Pliocene (sometime after $3 \mathrm{Ma}$, to explain the transport of material from the Wilkes/Pensacola Basins to form the Sirius Group, consistent with the views of Webb et al. 1984, McKelvey \& Stephenson 1990, Webb \& Harwood 1991, Wilson 1995).

The evidence that the Early Pliocene was warmer comes from both offshore and onshore data. The data and types of analysis are very different for the two environments. Conclusions from offshore information are based on (1) oxygen and carbon isotope signals contained in calcareous microfossils,

(2) analysis of intervals of erosion (identified as times of high cutrenc flow of the Antarctic Circumpolar Current) and deposition (evidence of decreased flow),

(3) variations in the timing and amount of ice-rafted debris, and

(4) features of the microfossils and the biota they represent, which are used as evidence of water temperature and its change.
The firss "modern" evidence for a warmer Pliocene came from the study of silicoflagellates from the marine environment (Ciesielski \& Weaver 1974), which showed that the Pliocene silicoflagellate flora is consistent with seawater temperature about $10^{\circ} \mathrm{C}$ warmer than present. Keany (1978) also spoke of Early Pliocene warming, as did Ciesielski et al. (1983). The warming is not for the entire Early Pliocene, but during the interval 4.5-3.9 Ma, part of the Gilbert Chron. Brady (1982) referred to the presence of marine fjord conditions in the Taylor and Wright Valleys in the Transantarctic Mountains during roughly the same interval. Abelmann et al. (1990) proposed a temperature higher by $5-10^{\circ} \mathrm{C}$ on the basis of radiolaria and diatoms. Burckle \& Pokras (1991) argued that a lower increase in temperature $\left(<3^{\circ} \mathrm{C}\right)$ was possible and Kennett \& Hodell (1995) indicated that they could accept a temperature no greater than $2.5^{\circ} \mathrm{C}$ warmer than now.

Several authors (Kennett 1985, Shackleton \& Opdyke 1977, Shackleton \& Cita 1979) have identified and commented on a $\delta^{18} \mathrm{O}$ shift towards heavier ocean water at about 3.5-3.4 Ma, indicating a different global ocean environment and decreased Pliocene global ice volume prior to that time. This transition was regarded as a time of possible Antarctic ice-volume growth (Kennett 1985).

Three lines of evidence are derived from onshore information. Pickard et al. (1986, 1988) reviewed data from Marine Plain, East Antarctica, based mainly on the results of examination of diatoms which showed that much of the in situ section there was deposited without evidence for the existence of sea ice. Shortly afterwards, Quilty (1991, 1992, 1993) recovered fossil dolphins and whales which appear to be from waters warmer than exist around Antarcrica at present. The recent discovery of a palinurid crustacean (Feldmann \& Quilty, in press) may be further evidence of warmer waters, as such crustaceans do not now occur around the Antarctic continent.

The most convincing evidence for warm conditions in the Late Pliocene/earliest Pleistocene comes from the discovery (Webb \& Harwood 1987, Carlquist 1987) of wood and leaves in the Sirius Group. The leaves (Nothofagus beardmorensis) have been described (Hill \& Truswell 1993 , Hill et al., in press) and the wood by Francis (1995) and Francis \& Hill (1996). These occur near the margins of the Beardmore Glacier at $86^{\circ} \mathrm{S}$, and much has been made of this as clear evidence of conditions much warmer there than exist at present, and consistent with an Antarctica ice sheet only about one-third of its present size. The time of alleged reduced ice sheet is $3-2.6 \mathrm{Ma}$, to explain the age of the youngest reworked fossils in the Sirius Group. Opponents (e.g. Burckle \& Pokras 1991) argue for a much greater age for the sediments (Oligocene or older).

\section{DEVELOPMENTS DURING 1995}

Since the publication of the Sugden et al. (1993) and Harwood (1994) reviews, the issue has advanced significantly, with the conduct by National Science Foundation of a workshop in Woods Hole, Massachusetts, in April 1995, to determine a way forward in resolving the debate, and also through papers presented at the 7 th International Symposium on Antarctic Earth Sciences (7 ISAES) held in Siena, Italy, in September 1995.

There have been some moves towards an acceptable common position on many issues. The antagonists seem to 
be able to accept the direcrion of the opposing argument, but never to the degree proposed. There appears to be consensus that there have been reductions and expansions of glaciation during the Pliocene, but not to an agreed position. There is agreement that there has been uplift of the Transantarctic Mountains (TAM), but not to the amount. Sea waters were warmer, but the amount is not agreed. It is agreed that sea level was higher, but the amount is dispuced

At the Woods Hole workshop, both sides were well represented and a spirited debate allowed quite clear identification of the viewpoints. Abstracts of that meeting are included in Kurz (1995), and van der Wateren \& Hindmarsh (1995) referred to the results. At the meeting, more evidence was presented to show that

(1) the Dry Valleys region has been little changed since the Miocene (Brook et al., Ivy-Ochs, Marchant),

(2) sea level varied by up to $60 \mathrm{~m}$ during the Late Pliocene and $40 \mathrm{~m}$ earlier than that (Brigham-Grette, Cronin et al., Ishman, Wilson),

(3) amino-acid racemisation studies on the Sirius Group wood yield a result consistent with a Pliocene age (Hill et al.),

(4) the extremes possible in the debate are a sea-level rise of $50-60 \mathrm{~m}$ or warming of the deep ocean by as much as $2.5^{\circ} \mathrm{C}$ (Hodell), and

(5) early evidence from the Prince Charles Mountains is consistent with Late Pliocene-Pleistocene glacial expansion of the scale needed to emplace the Sirius Group sediments (McKelvey).

At 7 ISAES, some stated well-known positions, but major advances were made by scientists outside the core groups. Francis (1995), in particular, reviewed the likely mode of existence for Nothofagus beardmorensis and compared it, nor with the Tasmanian $N$. gunnii or other Nothofagus species, but with the Arctic Dwarf Willow (Salix arctica). This lives to $85^{\circ} \mathrm{N}$ as a ground-hugging, straggling plant, which survives in an area with light conditions comparable with those in which $N$. beardmorensis existed but with an annual temperacure regime distinctly cooler than that required by the $N$. gunnii analogue.

At the same time, further discussion of the potential of the $\delta^{18} \mathrm{O}$ record to include some flexibility has paid dividends. This and other analyses allow a movement south of the Antarctic Polar Frontal Zone during the Early Pliocene, reduction in Antarctic ice volume by as much as one-third present volume (with consequent global sea-level rise signal) or a rise in seawater temperature around Antarctica by $1-2^{\circ} \mathrm{C}$. Kennett \& Hodell (1995) reviewed the issue again and stated that their analysis of the data allows extreme positions of a $35 \mathrm{~m}$ sea-level rise in the Early Pliocene, with a $1.4^{\circ} \mathrm{C}$ water temperature rise, or a seawater temperature $2.5^{\circ} \mathrm{C}$ warmer than present, but with little sea-level rise. Significant sea-level rise implies, of course, reduced Antarctic ice volume. It appears to be consistent with a sea-level rise of up to $25 \mathrm{~m}$ and water temperature abour $2^{\circ} \mathrm{C}$ warmer than the present.

These hyporhetical movements taken by the "general community" have taken much of the heat from the debate, while still leaving some way to go and also leaving the key antagonists locked in battle as a side issue.

The move should not be seen as any form of consensus science but as a genuine analysis of existing and new data to bring new ideas to the debate. Barrett et al. (1995) and Barrett (in press) helped this issue by calling for removal of labels (Stabilist, Dynamicist) from the groups and recognising that, in realicy, there is scope for flexibility in each stated position.

In addition, Harwood and Burckle, at 7 ISAES, both noted that the time involved is long and that there is scope for significant variation within the interval. Thus the idea of one model for the entire time is now gone.

\section{RESOLVING THE DEBATE}

The issue in question is whether or not the Antarctic ice sheet has been stable or dynamic between the Middle Miocene (say 15-14 Ma) and the present, even during intervals of relative global warmth, such as cimes within the Early Pliocene. There are quite profound implications for the world under an Enhanced Greenhouse Effect stemming from each case. If the stabilist view is correct, Antarctica may be expected to remain as it is now under some scenarios of a warmer earth; the dynamicist view is less reassuring.

A major issue remains the question of the age of the Sirius Group. There is no doubt that Late Pliocene diatoms and other fossils have been recovered from the sediments that constitute the Sirius Group in the TAM. But are the diatoms windblown in modern times or were they emplaced at the time the Sirius Group sediments were deposited? Are all sediments regarded as Sirius Group of one age or are many ages involved?

Pliocene diatoms are being windblown around Antarctica at present (Kellogg \& Kellogg 1996), and Burckle \& Potter (1996) recovered diatoms from many unusual sources, raising seriously the issue of the source of diatoms in the Sirius Group. At issue here are such questions as whether the Beardmore Glacier Sirius Group sediments are Late Pliocene (or even earliest Pleistocene), or much older but with windblown Late Pliocene diatoms. Burckle \& Pokras (1991) stated the case in support of a view that the sediments and their contained leaves are older Cenozoic (Oligocene or older), in conflict with the views of Harwood and collaborators, who believe the diatoms are coeval with the deposition of the sediments and macrofossils. It is essential that this problem be resolved by obtaining fresh samples from deep inside the formation and searching for diatoms that clearly are of the same age as the sediments (see Barrett et al. 1995).

These questions can be resolved only by a major dedicated program of documenting each outcrop in detail, including grain size, composition and source analysis, palaeontological study, palaeoenvironmental reconstruction, palaeomagnetic studies and eventual integration.

One major problem in the debare lies in the fact that a high proportion of the biostratigraphic data said to support the warmer Pliocene model is still unpublished. This shortcoming must be remedied before all the evidence can be evaluated and a conclusion reached.

The prime need in the debate is for new data on the issue and re-evaluation of some data that already exist. The region over which debate ranges is very large and the sources of data frustratingly few. The only in situ sediments are offshore cores and a few onshore sites, including Marine Plain in the Vestfold Hills, the Sirius Group sediments of the Transantarctic Mountains (which, while in situ as glacially deposited sediments, are not in situ as far as recycled fossils are concerned) and a few other localities, possibly 
Cockburn Island (Gazdzicki \& Webb 1996) and Prospect Mesa (Schlüchter \& Helfer in Kurz 1995).

The sediments attributed to the Early Pliocene could all have been deposited in a small part of this time, perhaps during some of the small peaks of apparently low ice volume/high sea level indicated on the curves reproduced in Tiedemann et al. (1994). There is a very real need to define better the time that is regarded as having been warm. Several authors (Brady 1982, Ciesielski et al. 1983, Ciesielski \& Weaver 1974) have indicated that the duration probably was during the interval 4.5-3.9 Ma, about onethird of the Early Pliocene.

How dynamic were the Transantarctic Mountains? Estimates of the amount of uplift of the TAM since the Pliocene vary from a few hundred metres to $3000 \mathrm{~m}$. Were the rate and amount constant along the entire mountain chain or do the blocks differentiated by Tessensohn (1994) have very different histories? Denton and co-authors in Sugden et al. (1993) argued a case for stability, but all their evidence came from the Dry Valleys Block (van der Wateren \& Verbers 1994, fig.1), where Sirius Group sediments are thin and limited in extent and have yielded only rare Pliocene diatoms (Harwood, pers. comm.). Van der Wateren \& Verbers (1994), reporting on the Admiralty Block of the Northern Victoria Land region, presented a very different case, with marked tectonism and uplift in the Pliocene. The story is consistent with the dynamicist argument but suffers from the apparent absence of Sirius Group sediments in the area. Similarly, Webb et al. (in press) argued for an uplift of at least $1331 \mathrm{~m}$ for Pliocene (possibly latest Miocene) sediments in the Queen Alexandra Block, south of the Dry Valleys. The contrasr between the histories of the Dry Valleys and Admiralty and Queen Alexandra Blocks seems to be very striking. Detailed analysis, akin to that conducted by Denton and co-authors for the Dry Valleys Block, is needed for each of the TAM blocks. Webb et al. (in press) began the process. Perhaps the hiscory of the Dry Valleys Block, strongly linked with that of the Victoria Land Basin offshore, is different from that of orher parts of the TAM, as suggested by Webb et al. (in press).

A major source of data may lie in the Prince Charles Mountains (PCMs) of East Antarctica, where recent studies (Bardin 1982, McKelvey \& Stephenson 1990, Laiba \& Pushina, in press) have proved the existence of young marine and nonmarine (Late Miocene-Pliocene) sediments containing diverse fossils and sequences that are in place. These indicate the existence of marine conditions during an interval which the stabilist hypothesis suggests should have been one of ice sheer comparable with the present. They show evidence of major changes of environment since deposition and of fjordlike depositional environments on a scale not known on earth at present. The area is under study in a coordinated program covering the entire area, not on the more piecemeal approach that scems to have been used in the Transantarctic Mountains. A corollary to the onshore work in the PCMs is the need for marine drilling of the Ocean Drilling Program type in the area offshore from the PCMs, in the Trough Mouth Fan in Prydz Bay (O'Brien \& Harris 1995), where much of the evidence eroded from the PCMs will lie.

One feacure that needs to be examined (and Prydz Bay Ocean Drilling may provide the answer) is the apparent absence of any Pliocene palynomorphs from sediments orher than those in the Sirius Formation. If a Nothofagus flora existed at high altitude at $86^{\circ} \mathrm{S}$, it probably existed elsewhere, especially in those areas which were farther north and at lower altitude and thus considerably warmer. While organic-walled microfossils are abundant in the in situ Early Pliocene at Marine Plain, none can be related to terrestrial vegetation (work in progress). If sediments of the Prydz Bay Trough Mouth Fan originated in the Prince Charles Mountains or around the margin of Prydz Bay, they should contain evidence of vegetation, if it existed.

Haq et al. (1987) produced curves of past sea-level variation, based on analysis of offshore seismic records from a great variety of locations around the world, excluding Antarctica. They identified several peaks of high sea level during the Pliocene, at 5-4 Ma about $90 \mathrm{~m}$ above modern sea level, at $3.5 \mathrm{Ma}$ at about $60 \mathrm{~m}$, and at $2.6,2.0$ and $1.2 \mathrm{Ma}$ about $20 \mathrm{~m}$ above modern sea level. These have been used to support the concept of Antarctic Early Pliocene warming and deglaciation (Quilty 1992). Other analyses (Dowsett \& Cronin 1990, Wardlaw \& Quinn 1991), based on other continental margin and island studies, indicate that there are problems with the calibration of the $\mathrm{Haq} e t$ al. curve, and that sea-level rises of greater than $35 \mathrm{~m}$ during the Pliocene are very unlikely (but see BrighamGrette in Kurz 1995, who argues for variation by as much as $60 \mathrm{~m}$ ). The 2.6,2.0 and 1.2 Ma peaks are considerably lower than those during the Early Pliocene, and this seems to be in conflice with the idea of a greater fluctuation in global ice volume and sea level during the Late Pliocene than during the Early Pliocene. Further work is needed to resolve the difference between the different approaches. If the Haq et al. curve is correct, it is very difficult to avoid the conclusion that the East Antarctic ice sheet is very dynamic.

Analyses of isotope data and of global ice-volume variation assume that all the factors are known and understood. It is essential that these assumptions do not detract from the debate about the facts based on ficld and laboratory observations. It is possible that there are factors not as yet taken into account.

\section{CONCLUSIONS}

The fascinating debate about the Pliocene environment of Antarcrica has not been resolved and will continue for many years. New data will emerge from more focussed research and a new group of scientists will become involved. Already, we have seen some convergence from what were deeply entrenched opposing views. The debate will lead to initiarives that are directed towards its resolution rather than to unrelated small projects which are of purely intrinsic scientific interest.

\section{ACKNOWLEDGEMENTS}

I am grateful to P. Barker, P. Barrett, J. Francis and D. Harwood, who responded so quickly to requests for information, to the email system that allowed such instant communication, and to those institutions (National Science Foundation, Australian Antarctic Division) that have made it possible to attend key meetings at key times. I also thank Drs J. Thiede and R. Tiedemenn of GEOMAR, Kiel, who arranged for the oxygen isotope data used for figure 3. Dr L. Belbin, Australian Antarctic Division, helped production of figure 3 and John Cox drafted other figures. 


\section{REFERENCES}

Abelmann, A., Gersonde, R. \& Spiess, V., 1990: PliocenePleistocene palcoceanography of the Weddell Sea siliceous microfossil evidence. In Bleil, U. \& Thiede, J. (Eds.): GEOLOGICAL HISTORY OF THE POLAR OCEANS: ARCTIC VERSUS ANTARCTIC. Kluwer, Amsterdam: 729-759.

BARdin, V.I., 1982: Composition of some East Antarctic moraines and some problems of Cenozoic hiscory. In Craddock, C.C. (Ed.): ANTARCTIC GEOSCIENCE. University of Wisconsin Press, Madison: 1069-1076.

BarReTT, P.J., in press: Antarctic paleoenvironments through Cenozoic times - a review. In Ricci, C.A. et al. (Eds): PROCEEDINGS VII INTERNATIONAL SYMPOSIUM ON ANTARCTIC EARTH SCIENCES, SIENA, SEPTEMBER 1995.

Barrett, P.J., Bleakley, N., Dickinson, W.W. \& Hannah, M.J., 1995: Occurence of diatoms in Sirius Diamictite on Mount Feather, Antarctica. In Ricci, C.A. et al. (Eds): VII INTERNATIONAL SYMPOSIUM ON ANTARCTIC EARTH SCIENCES, SIENA, September 1995, Abstracts 27.

Berger, A., Imbrie, J., Hays, J., Kukla, G. \& Saltzman, B., 1982: MILANKOVITCH AND CLIMATE: UNDERSTANDING THE RESPONSE TO ASTRONOMICAL FORCING. NATO ASI Series, series C: Mathematical and Physical Sciences, vol. 126. D. Reidel Publishing Company, Dordreche, 2 vols, $895 \mathrm{pp}$.

Brady, H.T., 1982; Late Neogene history of Taylor and Wright Valleys and McMurdo Sound, derived from diatom biostratigraphy and paleoecology of DVDP cores. In Craddock, C.C. (Ed.): ANTARCTIC GEOSCIENCE. University of Wisconsin Press, Madison: 1123-1131.

Burckle, L.H. \& Pokras, E.M., 1991: Implications of a Pliocene stand of Nothofagus (southern beech) within 500 kilometres of the South Pole. Antarct. Sci. 3: 389-403.

Burckle, L.H. \& POTTER, N. JR., 1996: Pliocene-Pleistocene diatoms in Paleozoic and Mesozoic sedimentary and igneous rocks from Antarctica: a Sirius problem solved. Geology 24: 235-238.

Carlouist; S., 1987: Pliocene Nothofagus wood from the Transantarctic Mountains. Aliso 1 1: 571-583.

Cifsielski, P.F. \& Wenver, F.M., 1974: Early Pliocene tempcrature changes in the Antarctic seas. Geology 2: $511-515$.

Ciesiel.ski, P.F., Ledbetter, M.T. \& Ellwood, B.B., 1983: The devclopment of Antarctic glaciation and the Neogene palcocnvironment of the Maurice Ewing Bank. Mar. Geol. 46: 1-51.

DeMracal, P.B., 1995: Plio-Pleistocene African climate. Science 270: 53-59.

DowseTT, H.J. \& Croniv, 'T.M., 1990: High eustatic sea level during the middle Pliocene: evidence from the soucheastern U.S. Atlantic Coascal Plain. Geology 18: $435-438$.

Feldomann, R.M. \& Quilty, P.G., in press: The first Pliocene decapod crustacean (Malacostraca: Palinuridae) from Antarctica. Antarct. Sci.

Francis, J., 1995: Growth forms of fossil trees and climatic implications for the Pliocene Sirius Group, Dominion Ranges, Transantarcric Mountains. In Ricci, C.A. et al. (Eds): VII INTERNATIONAL SYMPOSIUM ON ANTARCTIC EARTH SCIENCES, SIENA, September 1995, Abstracts 142.

Francis, J.E. \& Hill, R.S., 1996: Fossil plants from the Pliocene Sirius Group, Transantarcric Mountains: evidence for climate from growth rings and fossil leaves. Palaios.

GazDzicki, A. \& Webb, P.-N., 1996: Foraminifera of the Pecten Conglomerate (Pliocene), Cockburn Island, Antarctic Peninsula. Palacontol. Polonica, 55: 1-29.
HaQ, B.U., Hardenbol, J. \& Vall, P.R., 1987. The new chronostratigraphic basis of Cenozoic and Mesozoic sea level cycles. Cushman Found. Foramin. Res. Spec. Publ. 24: 7-13

Harwood, D.M., 1994: The continuing debate on Pliocene Antarctic deglaciation. In van der Wateren, F.M., Verbers, A.L.L.M. \& Tessensohn, F. (Eds): LANDSCAPE EVOLUTION IN THE ROSS SEA AREA, ANTARCTICA. Rijks Geologische Dienst, Haarlem: 101-105.

HiLl, R.S. \& TRUswell, E.M., 1993: Nothofagus fossils in the Sirius Group, Transantarctic Mountains: leaves and pollen and their climatic implications. In Kennert, J.P. \& Warnke, D.A. (Eds): THE ANTARCTIC PALEOENVIRONMENT: A PERSPECTIVE ON GLOBAL CHANGE. Am. Geophys. Union Antarct. Res. Ser. 60: $67-73$.

Hil.L, R.S., H^Rwood, D.M. \& WeBb, P.-N., in press: Nothofagus beardmorensis (Nothofagaceac), a new species based on leaves from the Pliocene Sirius Group, Transantarctic Mountains, Antarctica. Rev. Palaeobot. Palynol.

Hovghton, J.T., Jenkins, G.J. \& Ephraums, J.J. (Eds), 1990: INTERGOVERNMENTAL PANEL ON CLIMATE CHANGE: CLIMATE CHANGE: THE IPCC SCIENTIFIC ASSESSMENT. Cambridge University Press, New York: 364 pp.

KeAnY, J., 1978: Paleoclimatic trends in early and middle Pliocene deep-sea sediments of the Antarctic. Mar. Micropaleontol. 3: 35-49.

Kellogg, D.E. \& Kellogg, T.B., 1996: Diatoms in South Pole ice: implications for eolian contamination of Sirius Group deposits. Geology 24: 115-118.

Kennett, J.P., 1985: Miocene to Early Pliocene oxygen and carbon isotope stratigraphy in the Southwest Pacific, Deep Sea Drilling Project Leg 90. In Kennett, J.P., von der Borch, C.C. et al. (Eds): Initial Reps Deep Sea Drilling Proj. 90: 1381-1411.

Kennett, J.P. \& Hodell, D.A., 1993: Evidence for relative climatic stability of Antarctica during the Early Pliocene: a marine perspective. Geogr. Ann. 75A: 205-220.

Kennett, J.P. \& Hodell, D.A., 1995: Stability or instability of Antarctic ice sheets during warm climates of the Pliocene. GSA Today 5 (1): 1, 10,11, 12, 13, 22.

Kurz, M., 1995: Abstracts. Pliocene Antarctic Glaciation Workshop. Woods Hole Oceanographic Institution.

L.AIBA, A. \& PUSHINA, Z., in press: Neogene glacial-marine sediments and diatoms from Fisher Massif (Prince Charlcs Mountains). In Ricci, C.A. et al. (Eds): PROCEEDINGS VII INTERNATIONAL SYMPOSIUM ON ANTARCTIC EARTH SCIENCES, SIENA, SEPTEMBER 1995.

MarTin, H., 1991: Tertiary suratigraphic palynology and palacoclimate of the inland river systems in New South Wales. In Williams, M.A.J., De Deckker, P. \& Kershaw, A.P.(Eds): THE CAINOZOIC OF AUSTRALIA: A REAPPRAISAL OF THE EVIDENCE. Geol. Soc. Aust. Spec. Publ. 18: 181-194.

McKelvey, B.C. \& Stephenson, N.C.N., 1990: A geological reconnaissance of the Radok Lake area, Amery Oasis, Prince Charles Mountains. Antarct. Sci. 2: 53-66.

O'Brien, P.E. \& Harris, P.T., 1995: Prydz Trough Mouth Fan - a major record of Antarctic glacial history. In Ricci, C.A. et al. (Eds): VII INTERNATIONAL SYMPOSIUM ON ANTARCTIC EARTH SCIENCES, SIENA, September 1995, Abstracts.

Pickard, J., Adamson, D. A., Harwood, D.M., Miller, G.H., Quilty, P.G. \& Dell, R.K., 1986: Early Pliocene marine sediments in the Vestfold Hills, East Antarcrica: implications for coastline, ice sheet and climate. S. Afr. J. Sci. 82: 520-521.

Pickard, J., Adamson, D.A., Harwood, D.M., Miller, G.H., QuiLTY, P.G. \& DeLL, R.K., 1988: Early Pliocene marine sediments, coastline, and climate of East Antarctica. Geology 16: 158-161. 
Prentice, M.L. \& Matthews, R.K., 1991: Tertiary ice sheet dynamics: the snow gun hypothesis. J. Geophys. Res. 96: 6811-6827.

Quilty, P.G., 1991: The geology of Marine Plain, Vestfold Hills, East Antarctica. In Thomson, M.R.A., Crame, J.A. \& Thomson, J.W. (Eds): THE GEOLOGICAL EVOLUTION OF ANTARCTICA. Cambridge University Press, New York: 683-686.

Quilty, P.G., 1992: Late Neogene sediments of coastal East Antarctica - an overview. In Yoshida, Y., Kaminuma, K. \& Shiraishi, K. (Eds): RECENT ADVANCES IN ANTARCTIC EARTH SCIENCE. Terrapub, Tokyo: 699-705.

QuilTy, P.G., 1993: Coastal East Antarctic Neogene sections and their contribution to the ice sheet evolution debate. In Kennett, J.P. \& Warnke, D.A. (Eds): THE ANTARCTIC PALEOENVIRONMENT: A PERSPECTIVE ON GLOBAL CHANGE. Am. Geophys. Un. Antarct. Res. Ser. 60: 251-264.

Shackleton, N.J. \& Cita, M.B., 1979: Oxygen and carbon isotope stratigraphy of benthic foraminifers at Site 597: detailed history of climatic change during the late Neogene. In von Rad, U., Ryan, W.B.F. et al. (Eds): Initial Reps Deep Sea Drilling Proj. 47 (1): 433-445.

Shackleton, N.J. \& Kennett, J.P., 1975: Paleotemperature history of the Cenozoic and the initiation of Antarctic glaciation: oxygen and carbon isotope analyses in DSDP sites 277, 279, and 281. In Kennett, J.P., Houtz, R.E. et al. (Eds): Initial Reps Deep Sea Drilling Proj. 29:743755.

Shackleton, N.J. \& Opdyke, N.D., 1977: Oxygen isotope and paleomagnetic evidence for early Northern Hemisphere glaciation. Nature 270: 216-219.

Sugden, D.E., Marchant, D.R. \& Denton, G.H., 1993: The case for a stable East Antarctic ice sheet, Geogr. Annal. 75A (4): 155-351.

Sugden, D.E., Marchant, D.R., Potter, N. Jr, Souchez, G.H., SWISHER, C.C. III \& TISON, J.-L., 1995: Preservation of Miocene glacier ice in East Antarctica. Nature 376: $412-$ 414.

Tessensohn, F., 1994: Structural evolution of the northern end of the Transantarctic Mountains. In van der Wateren, F.M., Verbers A.L.L.M. \& Tessensohn, F. (Eds): LANDSCAPE EVOLUTION IN THE ROSS SEA AREA, ANTARCTICA. Rijks Geologische Dienst, Haarlem: 5761.

Tiedemann, R., Sarnthein, M. \& Shackleton, N.J., 1994: Astronomic timescale for the Pliocene Atlantic $\delta^{18} \mathrm{O}$ and dust flux records of Ocean Drilling Program site 659 Paleoceanography 9: 619-638.

TRUSWELL, E.M., 1982: Antarctica: the vegetation of the past and its climatic implications. Aust. Met. Mag. 30: 169-173.

TrusWell, E.M., 1990: Australian rainforests: The 100 million year record. In Webb, L.J. \& Kikkawa, J. (Eds): AUSTRALIAN TROPICAL RAINFORESTS: SCIENCEVALUE-MEANING. Commonwealth Scientific and Industrial Research Organisation (CSIRO), Melbourne: $7-22$.

Truswell, E.M., Chaproniere, G.C.H., \& Shafik, S., 1991: Australian Phanerozoic Timescales 10: Cainozoic. Bur. Miner. Resour. Geol. Geophys. Aust. Rec. 1989/40: 1-16.

VAN DER WATEREN, F.M. \& VERBERS, A.L.L.M., 1994: Differential tectonic uplift of fault blocks in the West Antarctic rift system and their landscape evolution histories. In Van der Wateren, F.M., Verbers, A.L.L.M. \& Tessensohn, F. (Eds): LANDSCAPE EVOLUTION IN THE ROSS SEA AREA, ANTARCTICA. Rijks Geologische Dienst, Haarlem: 125-128.

Van der Wateren, D. \& Hindmarsh, R, 1995: Stabilists strike again. Nature 376: 389-391.

Van der Wateren, F.M., Verbers, A.L.L.M. \& Tessensohn, F. (Eds), 1994: LANDSCAPE EVOLUTIONIN THE ROSS SEA AREA, ANTARCTICA. Rijks Geologische Dienst, Haarlem: $152 \mathrm{pp}$.

WARDLAW, B.R. \& QUINN, T.M., 1991: The record of Pliocene sea-level change at Enewetak Atoll. Quat. Sci. Rev. 10: 247-258.

WebB, P.-N. \& HaRwoOd, D.M., 1987: Late Neogene terrestrial flora of Antarctica: its significance in interpreting Late Cenozoic glacial history. U.S. Antarct. J. 22: 7-1 1.

WebB, P.-N. \& HArwood, D.M., 1991: Late Cenozoic glacial history of the Ross Embayment, Antarctica. Quat. Sci. Rev. 10: 215-223.

Webb, P.-N., Harwood, D.M., McKelvey, B.C., Mercer, J.H. \& STOTT, L.D., 1984: Cenozoic marine sedimentation and ice-volume variation on the east Antarctic craton. Geology 12: 287-291.

Webb, P.-N., Harwood, D.M., Mabin, M.G.C. \& McKelvey, B.C., in press: A marine and terrestrial Sirius Group succession, middle Beardmore Glacier-Queen Alexandra Range, Transantarctic Mountains, Antarctica. Mar. Micropaleontol.

WiLson, G.S., 1995: The Neogene Antarctic ice sheet: a dynamic or stable feature? Quat. Sci. Rev. 14: 101-123.

(accepted 13 August 1996) 